\title{
Genetic analysis of children with congenital ocular anomalies in three ecological regions of Nepal: a phase II of Nepal pediatric ocular diseases study
}

Srijana Adhikari ${ }^{1 *}$ D, Neelam Thakur², Ujjowala Shrestha ${ }^{3}$, Mohan K Shrestha', Murarai Manshrestha', Bijay Thapa ${ }^{4}$, Manish Poudel ${ }^{1}$ and Ajaya Kunwar ${ }^{5}$

\begin{abstract}
Background: Genetic eye diseases constitute a large and heterogeneous group of childhood ocular morbidity. Individual diseases may cause multiple structural anomalies and developmental features. Nepal Pediatric Ocular Disease Study (NPODS) was a population-based epidemiological study conducted across three ecological regions of Nepal to determine the prevalence and etiology of childhood ocular morbidity and blindness. In Phase II of this study, genetic analysis was performed for children who were found to have congenital ocular anomalies.

Method: It was a cross sectional descriptive study. A total of 10,270 children across three different ecological regions in Nepal (Low lands, hills, and mountains) underwent ocular examinations in NPODS. Out of 374 (3.6\%) of children with ocular abnormalities, 30 were thought to be congenital in nature. Targeted genetic analysis, including genotyping for genes specific to presenting phenotype, was performed for 25 children using serum samples.

Results: Out of 25 children, 18 had meaningful genetic results. Analysis revealed one missense alteration G12411T of Zinc Finger Homeobox 4 (ZFHX4) gene in one participant among 10 with congenital ptosis and another missense variation T > C P. Y374 C of Signaling Receptor and Transporter Retinol 6 (STRA6) gene in one participant among 3 with microphthalmos.

Conclusion: The study is first of its kind from Nepal and mutant genes were unique to Nepalese Population. Further analysis of genetic factors is crucial to better understand genetic association with ocular diseases and conditions. This helps further in genetic counseling and probably gene therapy to prevent blindness from these conditions.
\end{abstract}

Keywords: Nepal, Pediatric, Genetics, Congenital anomalies, Ocular

\footnotetext{
* Correspondence: srij_a@yahoo.com

${ }^{1}$ Tilganga Institute of Ophthalmology, PO Box 561, Kathmandu, Nepal

Full list of author information is available at the end of the article
}

C The Author(s). 2020 Open Access This article is licensed under a Creative Commons Attribution 4.0 International License, which permits use, sharing, adaptation, distribution and reproduction in any medium or format, as long as you give appropriate credit to the original author(s) and the source, provide a link to the Creative Commons licence, and indicate if changes were made. The images or other third party material in this article are included in the article's Creative Commons licence, unless indicated otherwise in a credit line to the material. If material is not included in the article's Creative Commons licence and your intended use is not permitted by statutory regulation or exceeds the permitted use, you will need to obtain permission directly from the copyright holder. To view a copy of this licence, visit http://creativecommons.org/licenses/by/4.0/. The Creative Commons Public Domain Dedication waiver (http://creativecommons.org/publicdomain/zero/1.0/) applies to the data made available in this article, unless otherwise stated in a credit line to the data. 


\section{Background}

Visual impairment is one of the most common disabilities affecting children. There is an estimated 1.4 million children worldwide who are blind, two-thirds of whom live in developing countries such as Nepal [1]. Controlling childhood blindness has been a top priority of the World Health Organization since its launch of the VISION 2020: The Right to Sight global initiative in 1999 [2].

Congenital ocular anomalies are one of the important causes of childhood ocular morbidity and blindness. Out of approximately 4000 genetic diseases and syndromes which affect humans, at least one third involves the eye $[3,4]$. The genetic and hereditary eye diseases account for $11-39 \%$ of childhood blindness with more common in developed than in the developing world [5] Treatment is unfortunately often difficult or nonexistent for many of these congenital anomalies. There is a limited understanding of these diseases and there is lack of clinical trial and testing of different therapies [6, 7].. Genetic testing in these situations can help to confirm diagnoses and thus provide prognostic information, guide interventions for the child, and assist in counseling regarding risk of disease occurrence in subsequent children. Pediatric Ophthalmologists are the ones who are on front line in assessing the patients and their families in these situation. There should be a good understanding and knowledge of various genetic tests indicated in different disease. The Genetic Eye Disease Task Force of the American Academy of Ophthalmology has recommended various genetic testing of different congenital ocular anomalies [8]. .

Phase I of Nepal Pediatric Ocular Disease Study (NPODS) determined the prevalence of childhood ocular morbidity and blindness across three ecological regions (lowlands, hills, mountains) of Nepal [9]. The three ecological regions were selected to represent Nepalese population with different socioeconomic and geographic background. The prevalence of childhood blindness was found to be $0.067 \%$ with congenital and hereditary ocular diseases accounting for $50 \%$ of blindness in children. Another study, a nationwide blind school survey done in Nepal found $30 \%$ of children suffering from hereditary diseases [10]. This burden of childhood blindness due to these congenital diseases is high. Managing these diseases becomes even more challenging in developing countries like Nepal due to lack of good infrastructure for clinical trial and tests. There is a handful of studies carried out in Nepal on genetic analysis of ocular diseases in adult populations [11]. There is no published study of such analysis in children. The Phase II of NPODS was carried out to find out risk factors of ocular morbidities identified in the first study [12]. In this Phase II study, we also conducted genetic analysis in children with congenital anomalies to understand the genetic implications of these diseases in Nepalese children. Looking at the frequency of mutation or allele in this type of congenital anomalies would help in future direction on diagnosis and management of these diseases in Nepalese population.

\section{Method}

This study was an expansion investigation from the phase I of NPODS. Children aged 0 to 16 years were included in the study. Congenital and hereditary ocular diseases were diagnosed by detailed history and clinical examination by Pediatric Ophthalmologists. After getting pre informed written consent at the time of examination, the children's parents were instructed to report to primary health center for blood sample collection. Children who did not show up for the sample collection and those who did not give consent were excluded from the study The genetic test was carried out in Kathmandu Centre for Genomics and Research Laboratory (KCGRL) in Kathmandu Nepal. A single $5 \mathrm{ml}$ venous blood sample was collected from each child while awake. DNA was extracted from the blood samples using a commerciallyavailable DNA Extraction Kit (Qiagen; city, state) as per manufacturer's protocol and after evaluation for quality. The extracted DNA was checked for the quality control through 1\% agarose gel electrophoresis using ethidium bromide as a staining dye. Genotyping was done for a selected number of specific genes which corresponded to the presenting phenotype of each child. (Fig. 1) Locations of mutations were identified by conventional methods as well as by available reference Single Nucleotide Polymorphism (SNP) ID. Genomic reference sequences, spanning the mutation locus were downloaded from db SNP as well as from Genbank database. Polymerase chain reaction primers to amplify these loci were designed using Primer design version 3 online tool. Primers were chosen such that they amplify 300-500 bp size amplicons and location of mutation is central to the amplicon with Sanger sequencing reads having high QV bars. Additional file 1 shows the primers designed to amplify each loci. In silico validation of these primer pairs was performed using NCBI Primer BLAST tool. Furthermore, Primers were designed using Chromosomal DNA reference sequence, db SNP reference sequences and primer 3 design software available at bioinfo.ut.ee/primer3-0.4.0. (Additional file 1) The Polymerase Chain Reaction (PCR) was carried out in a $25 \mu \mathrm{l}$ volume with the final mix containing $10 \times$ PCR buffer, $1.25 \mathrm{mM}$ dNTPs, $25 \mathrm{mM} \mathrm{MgCl}_{2}, 10$ pmole of each primer, $2.5 \mathrm{U}$ of $\mathrm{Taq}$ polymerase and $2.5 \mu \mathrm{l}$ of DNA template. The sample was heated to $95^{\circ} \mathrm{C}$ for $5 \mathrm{~min}$, followed by 35 cycles of $95^{\circ} \mathrm{C}$ for $30 \mathrm{~s}, 55^{\circ} \mathrm{C}$ for $30 \mathrm{~s}$, $72{ }^{\circ} \mathrm{C}$ for $30 \mathrm{~s}$ and a final extension at $72{ }^{\circ} \mathrm{C}$ for $10 \mathrm{mins}$. (Fig. 2). 


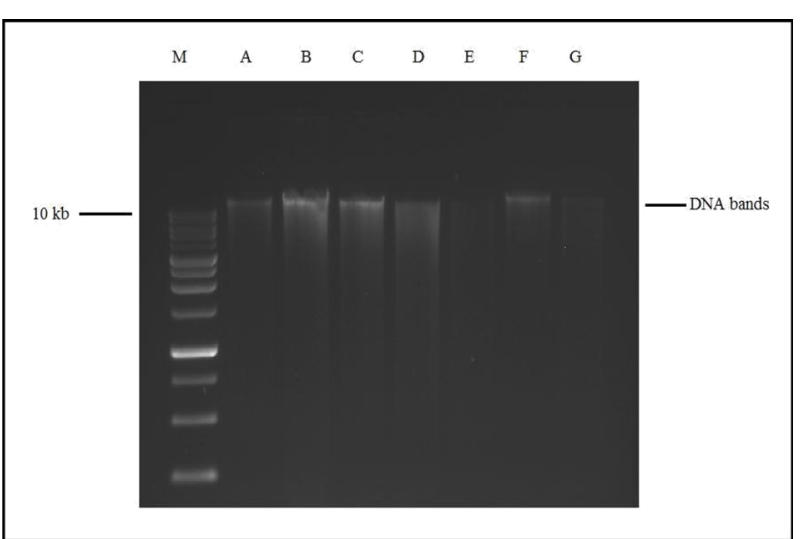

A: Congenital Ptosis, B: Congenital Cataract, C: Colobama, D: Microphthalmus, F: Crouzen Syndrome

Fig. 1 Agarose Gel electrophoresis

Through the confirmation from correct size of amplification, samples were further subjected to DNA sequencing. This DNA sequencing analysis was carried out to determine the precise order of nucleotides of given DNA molecule. It was used to determine the sequence of individual genes. (Additional file 2). Cycle sequencing reaction for each sample was performed in $0.2 \mathrm{~mL}$ PCR tube. The reaction included Terminator Ready Reaction Mix $\left(\right.$ BigDye $\left.^{\circ}\right)$ Terminator v3.1 Cycle Sequencing Kit, Applied Biosystems) $(0.5 \mu \mathrm{L})$, BigDye ${ }^{\bullet}$ Sequencing Buffer $(1.8 \mu \mathrm{L})$, One sequencing primer $(3.2 \mathrm{pmol})$, and template DNA $(2 \mu \mathrm{L})$ with Standard Milli Q (SMQ) water $(4.7 \mu \mathrm{L})$ to make up the volume of $10.0 \mu \mathrm{L}$. For each sample two sequencing reactions were performed; one using forward primer and other with reverse primer. The cycle sequencing protocol was as follows: Initial denaturation at $96^{\circ} \mathrm{C}$ for $1 \mathrm{~min}$, followed by 25 cycles of $96^{\circ} \mathrm{C}$ for $10 \mathrm{~s}$, annealing at $50^{\circ} \mathrm{C}$ for $5 \mathrm{~s}$, and elongation at $60^{\circ} \mathrm{C}$ for 4 min. (Additional file 3).

\section{Data management and analysis}

Data were entered into the electronic database The codes, recodes, consistency, outlines etc. were assessed through the use of Microsoft Excel. Data analysis was done in Statistical Package for Social Science (SPSS) version16. For the association of the categorical data, Chi Square test was used. $P$ value $<0.005$ was considered as statistically significant.

\section{Results}

A total of 10,270 children, aged 0 to 16 years across three different ecological regions of Nepal underwent vision screening Within this cohort, 5208 children (50.7\%) were from Lowland, 3136 (30.5\%) were from the hill, and $1926(18.8 \%)$ were from the mountain region. Ocular abnormalities were present in 374 (3.6\%) of all the children examined. The ocular abnormalities in 30 of these children were thought to be congenital in nature.

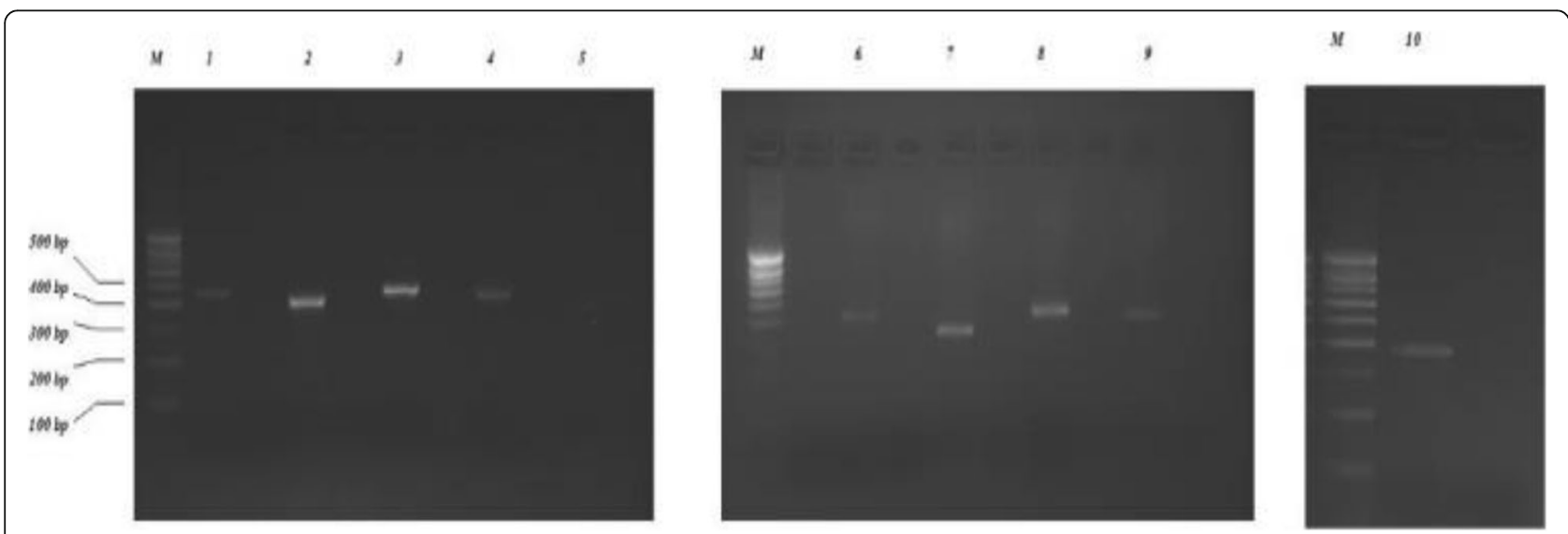

Fig. 2 Agarose Gel electrophoresis of PCR products on 2\% (wN) agarose gel 
Out of these the 30 children having congenital ocular anomalies, genetic analysis was carried out in 25 children. Five (16.7\%) children were non responders. The average (SD) age of study participants was 13.3 (3.1) years. Among 25 children, fifteen children (63.3\%) were male and $10(36.7 \%)$ were female. Within this group, 17 (68\%) children were from low land, $5(20 \%)$ were from the hill region, and $3(12 \%)$ were from the mountain region. Eleven (44\%) children had congenital ptosis, 5 (20.0\%) had congenital cataract, $4(16 \%)$ had iris and chorioretinal coloboma, 3 (12\%) had microphthalmos, 1 (4\%) had Nevus of Ota, 1 (4\%) had proptosis secondary to Crouzon syndrome, Table 1 shows the pattern of congenital ocular diseases across the three ecological regions. Most of the children with congenital anomalies were from the lowland. Out of 25 children who underwent genetic tests, meaningful genetic results could be found in 18 children. Two children were found to have mutant genes; one child with congenital ptosis and one with microphthalmous had mutation. Both of them were from lowland. The summary of different gene mutations has been shown in Table 2. The table shows that Ten SNP among seven genes for five congenital eye disorders listed above were selected. One missense alteration G12411T of ZFHX4 gene was identified in patient with congenital ptosis. (Fig. 3). Another missense variation $\mathrm{T}>\mathrm{C}$ P. Y374C of STRA6 gene was identified in patient with microphthalmos (Fig. 4). The proportion analysis was carried out to see the children with congenital and hereditary diseases having mutation versus non mutation in three ecological regions. (Table 3).

\section{Discussion}

In the current era of genetic advances, the diagnosis of genetic eye diseases is increasing and facilitated by collaborations between ophthalmologists and geneticists. Genetic testing can not only help confirm suspected diagnoses, but also provide important prognostic information and guide management for the individual affected and help provide appropriate genetic counseling for parents [13]. A comprehensive genetic evaluation

Table 1 Pattern of congenital ocular diseases in three ecological regions

\begin{tabular}{llll}
\hline Disease pattern & Low lands N(\%) & $\begin{array}{l}\text { Hills } \\
\mathbf{N}(\%)\end{array}$ & $\begin{array}{l}\text { Mountains } \\
\mathbf{N}(\%)\end{array}$ \\
\hline Coloboma & $4(16)$ & $0(0)$ & $0(0)$ \\
Congenital Ptosis & $7(28)$ & $3(12)$ & $1(4)$ \\
Congenital cataract & $3(12)$ & $1(4)$ & $1(4)$ \\
Microphthalmous & $3(12)$ & 0 & 0 \\
Nevus of Ota & 0 & 0 & $1(4)$ \\
Proptosis (Crouzen syndrome) & 0 & $1(4)$ & 0 \\
Total & $17(68)$ & $5(20)$ & $3(12)$ \\
\hline
\end{tabular}

requires a thorough clinical examination, a detailed family history, and access to advanced technology for molecular investigation [14].

We carried out the genetic analysis to find out molecular pattern and any significant mutations if present in Nepalese children with inherited eye diseases. In our study, congenital anomalies were most commonly present in Lowland region. The prevalence of congenital disease being more common in plain land is may be due to the fact that ocular morbidity and blindness as a whole was more common in this region. Moreover, the practice of consanguineous marriage is common in the community of this region which might have contributed to high prevalence of hereditary ocular diseases.

In our study, five types of congenital anomalies were studied; congenital ptosis, microphthalmos, congenital cataract, coloboma and Crouzon syndrome. Among these, only crouzon syndrome was found to be familial where mother was also affected.

Hereditary cataracts are clinically and genetically heterogeneous, often presenting as congenital or developmental cataracts that arises at birth or during the first few decades of life [15]. This is one of the important causes of avoidable blindness in children. Approximately $25 \%$ of non-syndromic cataracts are inherited [16]. They can also be grouped into three major classes, based on the functions of known underlying genes, those that code for crystallins, membrane/cytoskeleton proteins, and transcription factors. At least 35 independent loci, including more than 20 known genes, have been identified for non-syndromic cataract (Cat- Map) [17, 18]. Majority of missense mutations (nearly $50 \%$ ) is due to mutations in crystallin genes which is followed by mutations in the genes for cytoskeletal or membrane proteins (nearly 35\%) [17]. The Gap Junction Protein Alpha 8 (GJA8) and Gap Junction Protein Alpha 3 (GJA3) mutations together account for $20 \%$ of the reported total non-syndromic familial cataracts worldwide [17]. We selected a known SNP c.649G > A (Val196Met) from the same gene GJA8 and tested for the children with congenital cataract. This variation was not found in our patient with congenital cataract.

Another important congenital disease in our study was congenital ptosis. We selected one alteration in the ZFHX4 gene, G12411T L4137F in the children with congenital ptosis. This alteration was also reported previously in a Japanese family [19]. In our study this change was detected in one child with congenital ptosis.

Another group of children were with iris and chorioretinal coloboma and microphthalmia. Iris and Choroidal Choroidal and Microphthalmia are structurally related congenital eye malformations which display a spectrum of severity and can occur in isolation or as part of a syndrome [20]. Microphthalmia refers to a small eye, 
Table 2 The result summary of genetic analysis showing gene mutation

\begin{tabular}{|c|c|c|c|c|c|}
\hline $\mathrm{RN}$ & SN & Gene & Mutation & BASE Call & Result \\
\hline 1 & $A$ & ZFHX4 & G12411T L4137F & $T$ & G12411T detected \\
\hline 2 & B & GJA8_CX50 & c.649G > A (Val196Met) & G & c.649G > A Not detected \\
\hline 3 & $\mathrm{~F}$ & FGFR2 & S267P (T-C) & $\mathrm{T}$ & Not detected \\
\hline 3 & $\mathrm{~F}$ & FGFR2 & C278F (G-T) & G & Not detected \\
\hline 3 & $\mathrm{~F}$ & FGFR2 & Q289P (A-C) & A & Not detected \\
\hline 4 & $\mathrm{~F}$ & FGFR2 & C342S (G-C) & - & Not detected \\
\hline 4 & $\mathrm{~F}$ & FGFR2 & C342Y (G-A) & - & Not detected \\
\hline 4 & $\mathrm{~F}$ & FGFR2 & C342W (C-G) & - & Not detected \\
\hline 4 & $\mathrm{~F}$ & FGFR2 & A344A (G-A) & - & Not detected \\
\hline 4 & $\mathrm{~F}$ & FGFR2 & S347C (C-G) & - & Not detected \\
\hline 5 & $D$ & STRA6 & T>C P.Y374C & C & T>C P.Y374C detected \\
\hline 6 & $\mathrm{D}$ & STRA6 & A > T P.L152M & T & L152L present, mutation not detected. \\
\hline 7 & $\mathrm{D}$ & CRYBA4 & C > T P.R25W & C & Mutation not detected \\
\hline 8 & $\mathrm{D}$ & OTX2 & p. $G \ln 104 X$ & C & p. Gln104 X Not detected \\
\hline 8 & $\mathrm{D}$ & OTX2 & p. Gln106 His & C & p. Gln106 His Not detected \\
\hline 9 & $\mathrm{D}$ & OTX2 & p. Thr186 Fs $<$ frame shift & G & p. Thr186 Fs $<$ frame shift Not detected \\
\hline 10 & C & $A B C B 6$ & p. Ala 57 Thr G > A & G & p. Ala 57 Thr G > A Not detected \\
\hline
\end{tabular}

$\mathrm{SN}=$ Sample number, $\mathrm{RN}=$ reaction number Where, A: Congenital Ptosis, B: Congenital Cataract, C: Colobama, D: Microphthalmus, F: Crouzon Syndrome

defined by axial length. Iris coloboma is a segmental ocular defect resembling a key hole deficiency in iris. Chorioretinal coloboma is associated with iris coloboma and visually significant if posterior pole is involved [21].. The STRA6 gene plays a key role in normal ocular development, encoding a transmembrane receptor for the retinol-binding protein (RBP) and is responsible for mediating vitamin A uptake from circulation to target organs including the eye [22]. We selected two SNP in STRA6 ( T > C P. Y374C and A > T P. L152M) gene which are already found in database. We could identify one of these mutations in our patient.

The second gene we selected was Crystalline Beta A 4 (CRYBA4). It is a known fact that complex microphthalmia in association with genetic cataracts has been attributed to mutations in the CRYBA4 gene [23]. We selected one SNP C>T P. R25W from CRYBA4 gene which could not be identified in our patient.

The next gene was Orthodenticle Homeobox 2 (OTX2). The OTX2 gene encodes a transcription factor

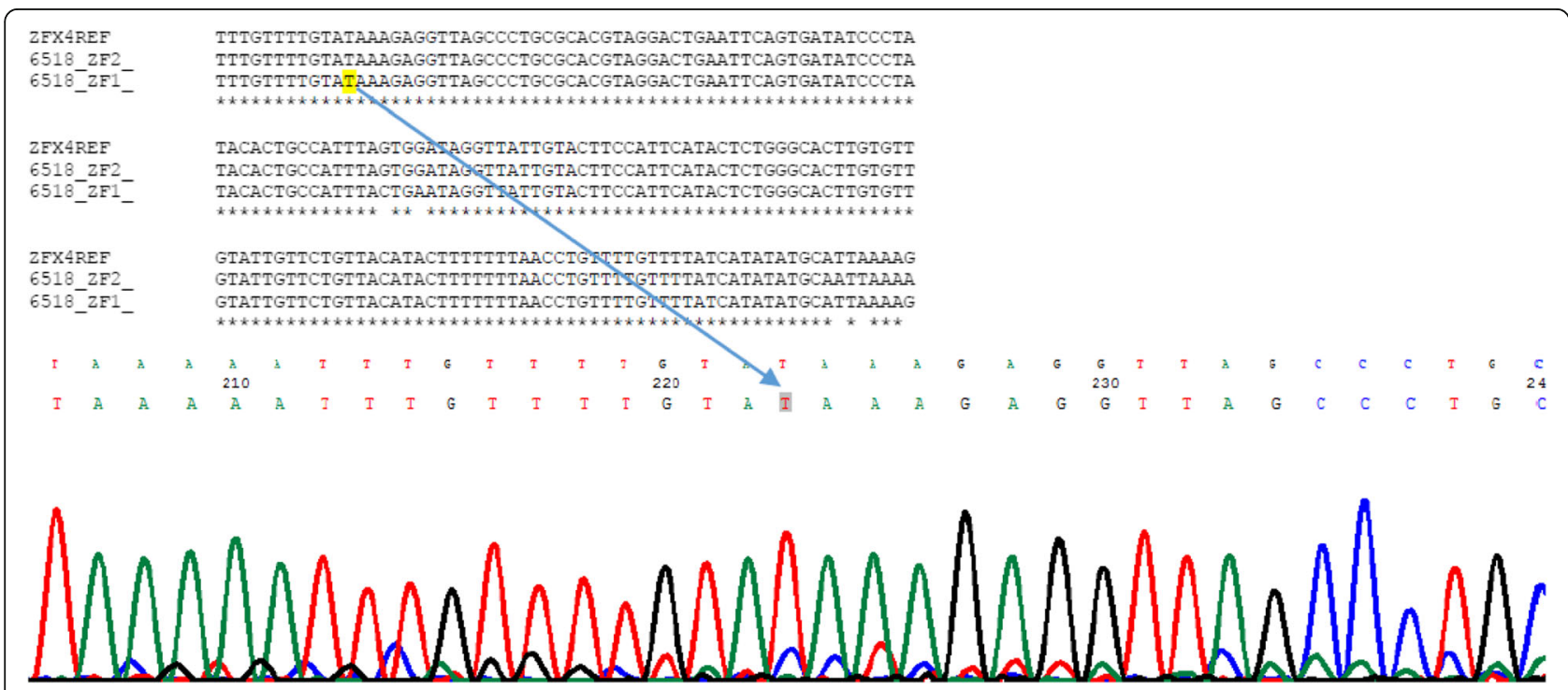

Fig. 3 Sequence result of G12411TL4137F mutation in ZFHX4 gene in a child with congenital Ptosis 


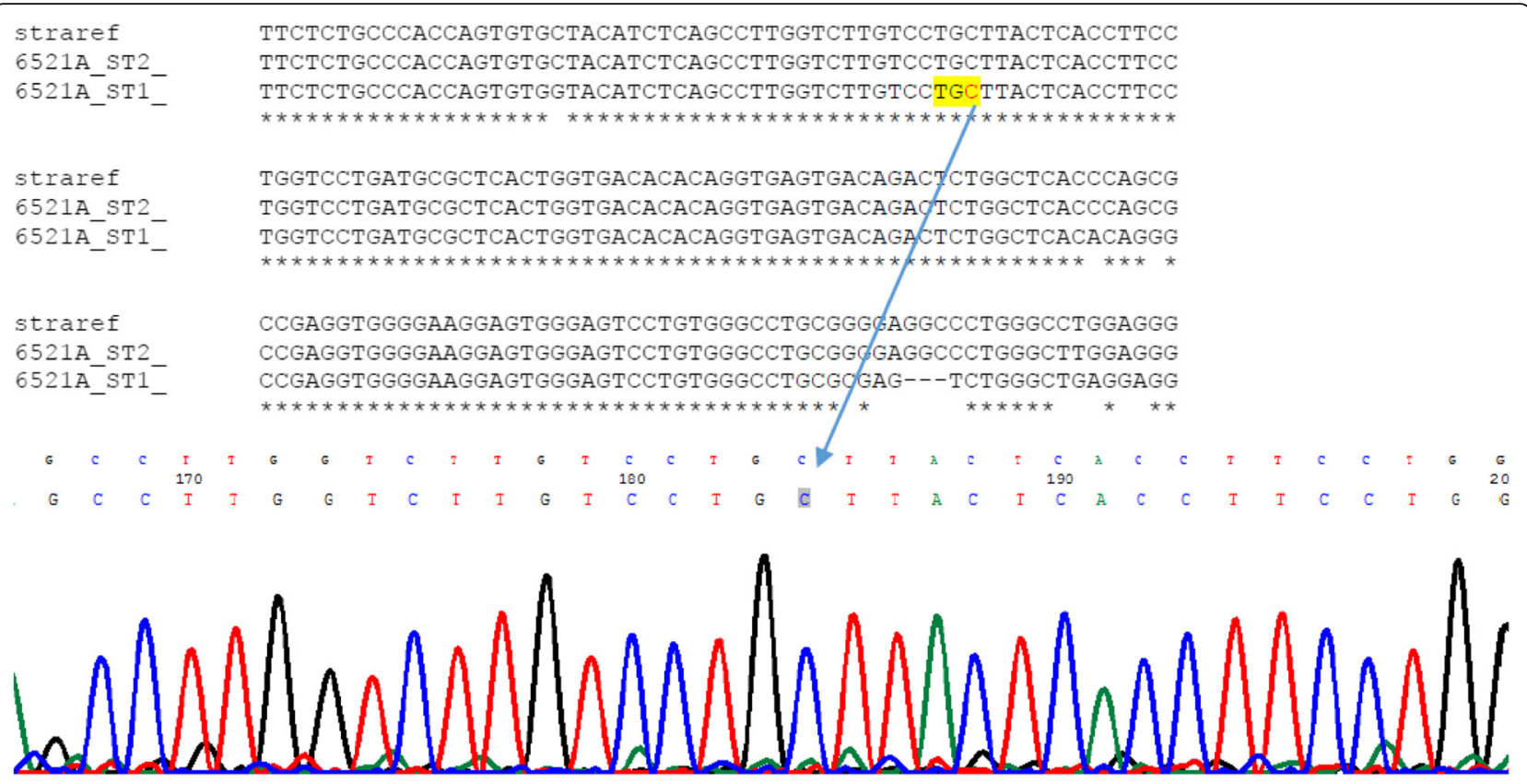

Fig. 4 The T > C P. Y374C mutation in STRA6 gene in a child with micropthalmous

critical for forebrain and eye development [24]. The OTX2 protein contains a homeodomain, responsible for DNA binding, SGQFTP and SIWSPA motifs involved in protein-protein interactions, and two C-terminal tandem OTX-tail motifs responsible for transactivation [25]. We selected three SNP p. Gln104 X, p. Gln106 His, p. Thr186 Fs $<$ frame shift from OTX2 gene which could not be identified in our patient.

Another gene we selected was one SNP p. Ala $57 \mathrm{Thr}$ GA, from the ATP Binding Cassette Sub Family B Member 6 (ABCB6) gene, which is involved in the active transport of various compounds vital for CNS development [26]. However, we could not identify this mutation in our patient. Another important hereditary disease was Crouzon syndrome which is an autosomal dominant craniosynostosis disorder which is caused by mutation in the Fibroblast Growth Factor Receptor 2 (FGFR2) genes [27]. We selected few SNP from FGFR2 gene, for crouzon syndrome which codes for fibroblast growth factor receptor, but mutation was not found in this patient as

Table 3 Proportion analysis of disease according to presence or absence of mutant gene and the region

\begin{tabular}{llll}
\hline Variables & category & $\mathbf{N}(\%)$ & $\mathbf{p}$ \\
\hline Region & Mountain & $2(8)$ & $<0.001$ \\
& Hill & $5(20)$ & \\
Mutation & Terai & $18(72)$ & \\
& Absent & $23(92)$ & $<0.001$ \\
\hline
\end{tabular}

well. The limitation of our study is the small sample size. From a large population based sample, we selected those children for genetic analysis who had congenital ocular anomalies. Sample size could have been increased by recruiting children from the hospital based data. Another limitation is the pattern of diseases which were studied. We could widen our research in other types of congenital ocular disease as well. Carrying out genetic screening in Nepal is challenging with limited resources and high cost.

\section{Conclusion}

Our study was the first of its kind in Nepal to identify genetic mutations associated with congenital ocular anomalies. Through our analysis, two new mutations were identified in children with congenital ptosis and the microphthalmos unlike other studies on genetic analysis of congenital ptosis and microphthalmos. Further analysis of genetic factors including wide range of genetic and hereditary ocular diseases is crucial to better understand their genetic association.. This helps further in genetic counseling and probably gene therapy to prevent childhood blindness.

\section{Supplementary information}

Supplementary information accompanies this paper at https://doi.org/10. 1186/s12881-020-01116-9.

Additional file 1. Primer names with sequence and PCR products in different diseases 
Additional file 2. Samples with further DNA sequencing. A: Congenital Ptosis B: Congenital Cataract C: Colobama D: Micropthalmus F: Crouzen Syndrome

Additional file 3. The results of the sequencing analysis of primers.

\section{Abbreviations}

NPODS: Nepal Pediatric Ocular Disease Study); STRA6: Signaling Receptor and Transporter Retinol 6; ZFHX4: Zinc Finger Homeobox 4; KCGR L: Kathmandu Centre for Genomics and Research Laboratory; SNP: Single Neucleotide Polymorphism; PCR: Polymerase Chain Reaction; dNTPs: Deoxy Nucleotide Triphosphates; SMQ: Standard Milli Q; SPSS: Statistical Package for Social Science; GJA8: Gap Junction Protein Alfa 8; RBP: Retinol Binding Protein; CRYBA4: Crystallin Beta A 4; OTX2: Orthodenticle Homeobox 2; ABCB6 Gene: ATP binding Cassette Subfamily B Member 6; FGFR 2: Fibroblast Growth Factor Receptor 2

\section{Acknowledgements}

We Acknowledge the Fred Hollows Foundation for providing a research grant in support of this study. We acknowledge Dr. Sophia Fang, Pediatric Ophthalmologist from University of Utah for helping in grammar check and manuscript.

\section{Authors' contributions}

All authors have read and approved the manuscript. Each author's contribution in carrying out this research and writing the manuscript has been listed as follows. SA: Principal investigator of this research and wrote most parts of the manuscript. NT: Clinical genetic specialist helped in manuscript preparation and genetic analysis. US: Helped in manuscript preparation. MKS: Helped in manuscript preparation and study design. MMS: Helped in study design. MP: Helped in data analysis. BT: Helped in study design. AK: Helped in research design and genetic analysis

\section{Funding}

The study was carried out from the research grant provided by the Fred Hollows Foundation Australia. This fund was used for conducting field visit for Examination of children and carrying out genetic test of children in the lab. The grant which was provided in the first phase of NPODS was continued in the second phase. We received only the financial support from the funders but they don't have any technical role in conducting the research and in write up.

\section{Availability of data and materials}

The datasets used and/or analyzed during the current study are available in the link https://osf.io/4yezc/?view_only=cc9fbeb0693a46e4852384a606faf6ec, $\mathrm{dbSNP}$ reference sequences and Primer3 primer design software available at bioinfo.ut.ee/primer3-0.4.0. http://www.genome.jp/tools/clustalw/

\section{Ethics approval and consent to participate}

This study was approved by the Institutional Review Committee of the Tilganga Institute of Ophthalmology. The study adheres to the tenets of the Declaration of Helsinki. The written informed consent was obtained from a parent or guardian for participants under 16 years old.

\section{Consent for publication}

Not applicable.

\section{Competing interests}

The authors declare that they have no competing interests.

\section{Author details}

${ }^{1}$ Tilganga Institute of Ophthalmology, PO Box 561, Kathmandu, Nepal. ${ }^{2}$ National Academy of Medical Sciences NAMS, Bir Hospital, Kathmandu, Nepal. ${ }^{3}$ Sudrishti Eye Clinic, Kathmandu, Nepal. ${ }^{4}$ Patan Academy of Health Sciences, Patan, Nepal. ${ }^{5}$ The Kathmandu Centre for Genomics and Research Laboratory, Kathmandu, Nepal.
Received: 6 May 2020 Accepted: 31 August 2020

Published online: 22 September 2020

\section{References}

1. WHO: Program for the Prevention of Blindness and Deafness, Global initiative for the elimination of avoidable blindness. Geneva WHO; 2000

2. Gilbert C, Foster A. Childhood blindness in the context of VISION 2020-The right to sight. Vol. 79, Bulletin of the World Health Organization. 2001.

3. Griffin JR. Genetics review: relation to ocular disease. Optom Vis Sci. 1994;71: 164-7.

4. MacDonald IM, Mah DY. Summary of heritable ocular disorders and selected systemic conditions with eye findings. Ophthalmic Genet. 2000; 21:29-49.

5. Gilbert $C^{1}$, Rahi J, Eckstein M, Foster A Mar;16(1):1-10 Hereditary disease as a cause of childhood blindness: regional variation. Results of blind school studies undertaken in countries of Latin America, Asia and Africa. Ophthalmic Genet. 1995.

6. Young TL. Ophthalmic genetics/inherited eye disease. Curr Opin Ophthalmol. 2003;14:296-303.

7. S Afr Optom 2012 71(4) 178-189 A review of ocular genetics and inherited eye diseases SD Mathebula.

8. The American Academy of Ophthalmology Task force on Genetic Testing Recommendation for genetic testing of inherited eye diseases. Guidelines of American Academy of ophthalmology, February 2014.

9. Adhikari S, Shrestha MK, Adhikari K, Maharjan N, Shrestha UD. Causes of visual impairment and blindness in children in three ecological regions of Nepal: Nepal pediatric ocular diseases study. Clin Ophthalmol. 2015 Aug 25; 9:1543-7.

10. Shrestha JB, Gnyawali S, Upadhyay MP. Causes of blindness and visual impairment among students in integrated schools for the blind in Nepal. Ophthal Epidemiol. 2012;19(6):401-6.

11. Jhonson MP, Thapa,S Laston S. Genetic Research on Ocular Health and Disease in a Population from Nepal: Genetic Eye Research in Asia and the Pacific. Chapter · January 2019. DOl: https://doi.org/10.1007/978-981-130884-0_ 8 .n book: Advances in Vision Research, Volume II, pp.75-84.

12. Adhikari S, Shrestha U, Shrestha MK, Paudyal M, Thapa B, Shrestha M. Environmental factors associated with ocular morbidity among children in three ecological regions of Nepal: a phase II Nepal pediatric ocular diseases study Int Ophthalmol; 2017 Oct 14

13. Singh M, Tyagi SC. Genes and genetics in eye diseases: a genomic medicine approach for investigating hereditary and inflammatory ocular disorders. Int J Ophthalmol. 2018:11(1):117-134. Published 2018 Jan 18. doi:https://doi. org/10.18240/ijo.2018.01.20.

14. Elias I. Traboulsi. MD: Genetic Diseases of the Eye, Second Edition, Oxford University Press; 2012.

15. Holmes JM, Leske DA, Burke JP, Hodge DO. Birth prevalence of visually significant infantile cataract in a defined U.S. population. Ophthalmic Epidemiol. 2003;10:67-74. 12660855.

16. Foster A, Gilbert C, Rahi J. Epidemiology of cataract in childhood: a global perspective. J Cataract Refract Surg 1997: 23: Suppl 1601-4. [PMID: 9278811.

17. He W, Li S. Congenital cataracts: gene mapping. Hum Genet. 2000;106:1-13.

18. Shiels A, Bennett TM, Hejtmancik JF. Cat-Map: putting cataract on the map. Mol Vis 2010; 16:2007-

19. Mitsuko Nakashima Æ.. Motoi Nakano, genome-wide linkage analysis and mutation analysis of hereditary congenital blepharoptosis in a Japanese family. J Hum Genet. 2008:53:34-41.

20. Morrison D, FitzPatrick D, Hanson I, J National study of microphthalmia, anophthalmia, and coloboma (MAC) in Scotland: investigation of genetic aetiology. J. Med. Genet. 39, 16-22.

21. Myron S Yanoff J S Duker,Ophthalmology $5^{\text {th }}$ Edition United states of America. Elsiever 2019.

22. Kawaguchi R, Yu J, Honda J, Hu J. A Membrane Receptor for Retinol Binding Protein Mediates Cellular Uptake of Vitamin A Science. 2007 Feb 9: 315(5813):820-5

23. Billingsley $\mathrm{G}$, Santhiya ST. CRYBA4, a novel human cataract gene, is also involved in Microphthalmia. Am J Hum Genet. 2006 Oct;79(4):702-9.

24. Beby F, Lamonerie T. The Homeobox Gene Otx2 in Development and Disease. Exp Eye Res. 2013 Jun; 111):9-16. 
25. Deml B. Linda M Reis, novel mutations in PAX6, OTX2 and NDP in anophthalmia, microphthalmia and coloboma. Eur J Hum Genet. 2016 Apr; 24(4):535-41.

26. Wang L. $A B C B 6$ mutations cause ocular Coloboma, the American journal of human genetics 90, 40-48. January. 2012;13.

27. Rivka L. Glaser, wen Jiang, paternal origin of FGFR2 mutations in sporadic cases of Crouzon syndrome and Pfeiffer syndrome. Am J Hum Genet. 2000; 66:768-77.

\section{Publisher's Note}

Springer Nature remains neutral with regard to jurisdictional claims in published maps and institutional affiliations.

Ready to submit your research? Choose BMC and benefit from:

- fast, convenient online submission

- thorough peer review by experienced researchers in your field

- rapid publication on acceptance

- support for research data, including large and complex data types

- gold Open Access which fosters wider collaboration and increased citations

- maximum visibility for your research: over $100 \mathrm{M}$ website views per year

At $B M C$, research is always in progress.

Learn more biomedcentral.com/submissions 